\title{
ONLINE GROCERY SHOPPING ACCEPTANCE: THE IMPACT ON THE PERCEPTION OF NEW TECHNOLOGIES AND LOYALTY IN RETAILING
}

\section{Bauerova, R.}

Radka Bauerova / Silesian University, School of Business Administration in Karvina, Department of Business Economics and Management, Univerzitni nam. 1934/3 73340 Karvina, Czech Republic. Email: bauerova@opf.slu.cz

\begin{abstract}
Online grocery shopping is becoming an integral part of life for more and more customers around the world and has truly changed the way consumers acquire their groceries. Nevertheless, the offline environment is still a priority for most customers. Therefore, it is not surprising that new technologies are also being introduced in traditional stores. The purpose of this paper is to explore if all generations of customers equally perceive pressure to apply new technologies into the purchasing process and how previous online grocery shopping acceptance can influence customer behaviour. This research was conducted on a sample of 1,050 online respondents. The answers of respondents have a nominal character. Therefore, Pearson's chi-square test was used for testing. Subsequently, the frequency analysis was used for a more detailed examination. The results indicate that online grocery shopping acceptance positively influences the perception of new technologies from the perspective of all generations of customers. An interesting finding is that if traditional retailers entered the online market, $67 \%$ of online grocery shoppers would change retailers. This paper brings a new perspective on online and offline generations of customers and states that online grocery shopping acceptance is a predictor of positive perception of other technologies in retailing. Managers should take steps to increase the acceptance of technologies in stores, which will facilitate the business processes in the store and optimize the use of the workforce. This paper also demonstrates an opportunity for traditional retailers to enter the online marketplace.
\end{abstract}

Keywords: grocery retailing, online grocery shopping, new technologies, technology acceptance, customer behaviour

JEL Classification: M19, M31

\section{Introduction}

In the context of globalization and internationalization of trade, customers' buying behaviour has changed. This has led to pressure to improve the service quality and innovation provided in retail. The retailers strive for competitive advantages through better customer relationship management via customer databases with growing globalization, market saturation, and increased competitiveness through mergers and acquisitions (Anderson et al., 2007). They 
have realized that customer relationships are an essential tool for building and raising customer value, which is subsequently the key to increasing value for the company (Rogers, 2005). Organizational systems and processes, most of which are associated with data and information management, are changing in response to this shift toward customer-focused retail (Anderson et al., 2007). The retail shopping format is currently affected by changes in the rapid development of the internet with the application of new technologies to improve the overall customer shopping process, thereby causing pressure to change established business strategies. Three types of business models exist within the context of the grocery shopping sector. These include the "brick and mortar" used in traditional retail chains (Inc \& Linsenmann, 2015), "pure-play" used only by online retailers (Flanc, 2014), and "bricks and clicks" used by retailer traders online and offline through their offline chain store (known as multichannel retailing) (Fleisher \& Bensoussan, 2015). This paper focuses on the perceptions of technologies usable in "brick and mortar" and "pure-play" business models.

Newer technologies and business models, and big data /predictive analytics suggest that the shopping process is on the verge of a quantum leap into an unknown shopping realm (Grewal et al., 2017). The importance of new technologies in retailing is demonstrated by many studies oriented on consumers' behaviour (Kim, Libaque-Saenz, \& Park, 2019; Izogo \& Jayawardhena, 2018), new business models (Jocevski, Arvidsson, Miragliotta, Ghezzi, \& Mangiaracina, 2019), technologies in retailing such as virtual reality (Violante, Vezzetti, \& Piazzolla, 2019; Huang, 2019), augmented reality (Esch et al., 2019), and also the changes in retailing reality in some shops (Pantano \& Vannucci, 2019). The purpose of this paper is to provide an overview of what technology can be used in grocery retail and how these technologies are perceived by customers. The primary research focused on selected technologies and their perception by customers purchasing groceries. The aim of the paper is to explore whether online grocery shopping acceptance affects the perception of new technologies and loyalty in grocery retailing. Within the second part of the paper, the growth potential of new technologies in grocery retail is presented and hypotheses are formulated. In the next section, the research sample, data analysis, and statistical methods are described. Then, the results of the analysis are presented in section four. The last section summarizes and discusses the research findings, implications for theory and practice, together with the limitations of the research.

\section{Literature review and research hypotheses}

Retail is evolving at an accelerated rate due to changes made possible by new technologies which influence how shoppers select channels, choose products and services, make purchases, and consumers' expectations of new technologies (Grewal et al., 2017; Pantano \& Vannucci, 2019). Examples of these new technologies include touch screen stands, electronic rack labels, virtual and augmented reality, and smart sales machines (Pantano \& Priporas, 2016). The most effective way to involve potential and existing customers into the purchasing process and bring a better-added value to them is integrating these innovative technologies into retail practice (Pantano et al., 2017). Today, not only new technologies such as portable touch scanners, smart baskets, and self-service cash desks in traditional stores are being added to everyday retailing, but also the expansion of online forms of grocery purchases are taking place (Bauerova, 2018). It was found that the actual retailers' demand of new technologies includes info/product display technologies, shopping experience 
technologies, information search technologies, payment technologies, and other technologies (i.e. click and collect, vending machine, intelligent self-service kiosk) (Pantano \& Vannucci, 2019). This paper focuses on the Scan\&Go service, smart shopping carts, selfservice cash registers, and customerization support technologies as a part of the new technologies used in current retail. These technologies are specified as follows:

- Self-check-out technology helps shoppers scan, bag, and pay for products without any need to interact with a cashier. Customers gain control and retailers enjoy reduced labour costs due to the fewer number of cashiers required (Inman \& Nikolova, 2017).

- Scan-and-go technologies allow customers to use their smart-phones to scan items as they shop, then use the retailer's app to pay, or use retailers' scan device to scan items and pay (Grewal et al., 2017).

- Radio-frequency identification (RFID) technology allows customers to use smart shopping carts equipped with electromagnetic fields for automatically identifying and tracking tags attached to goods for sale. These carts are equipped with scanners that track the total price of a customers' shopping basket as they shop, which help them better track their in-store spending (Ittersum et al., 2013).

- Customerization support technologies include all technologies designed to customize products directly for customers. Customerization is a new type of mass customization, where the customer is an active co-producer. Organizations can use different technologies for customerization such as 3-D scanning and modelling, 3-D printing (Gandhi, Magar, \& Roberts, 2013), or developing platforms that allow customerization (Wind \& Rangaswamy, 2001). These platforms can, for example, be used in grocery retail to choose personalized food and vitamins based on nutritional needs (Gandhi, Magar, \& Roberts, 2013).

Using market segmentation analysis, it is possible to group consumers into naturally existing or artificially created segments of consumers who share similar product preferences or characteristics (Dolnicar et al., 2018). This paper focuses on the generation to which individual respondents belong and the technology acceptance of online grocery shopping as possible variables that can be used in segmenting customers. Three generations of customers are analysed for the purpose of this paper. The generation Baby Boomers (more than 53 years), Generation X (38 - 52 years) and Generation $Y(18-37$ years) are included in this research (Hole et al., 2012). The technologies with which these generations grew up with are different. While Baby Boomers grew up with radio, television and the fax machine, Generations $X$ and $Y$ grew up with computers, cell phones, internet, and other variations of these technologies (Wiley, 2019). This situation has caused different perceptions and acceptance of technologies between generations. Baby Boomers adapt more slowly to technology in spite of the fact that they experienced technology changing over the years and saw how it made life easier (Slootweg \& Rowson, 2018). Generation X recognizes how technology has changed their world and techno-literacy is highly valued by them (Fox, 2014). Generation $Y$ uses technology almost constantly and cannot imagine a day without it (Slootweg \& Rowson, 2018). In the case of digitalization of grocery shopping from a generation perspective, differences in purchasing motives have been identified (Bauerova \& Klepek, 2018), but the impact of technological acceptance in online and offline customers' 
generation groups have not been investigated. Based on that, these hypotheses were formulated as:

Hypothesis 1: The positive perception of new technologies in grocery retail diminishes with the growing age range of generations of customers purchasing groceries.

Hypothesis 2: Online grocery shopping acceptance diminishes the negative perception of new technologies in grocery retail, particularly when considered in terms of the growing age range of generations of customers purchasing groceries.

The differences between online and offline grocery shoppers have been explored from different perspectives. Some studies have focused on the differences in consumer behaviour of these groups (Munson et al., 2017; Harris, Riley, Riley, \& Hand, 2017), while others have examined the perception of technology and innovation (Maat \& Konings, 2018; MolinerVelázquez et al., 2019) or on differences in loyalty (Saini \& Lynch, 2016; Danaher et al., 2003). The research in this paper will focus on differences in the acceptance of new technologies and loyalty between online and offline grocery customers. According to Maat and Konings (2018), online grocery shoppers are a small group of customers, however, research suggests that this group is more open to new technologies. This is also confirmed by the fact that the online shopper profile is dominated by young people as they are typically more likely to adopt new technologies, live in households with internet access, and have higher levels of internet use (Hernández et al., 2011). The difference between online and offline grocery shoppers' loyalty is another area of research in this paper. Chen and Yen (2014) identified that trust and customer satisfaction act as mediators in the relationship between service quality and e-loyalty. However, according to Azhar and Bashir (2018), this assumption does not apply to online grocery shoppers. They claim that e-loyalty in online grocery shopping is not affected by e-satisfaction nor the variables such as convenience, merchandising, site design, or financial security. According to them, e-loyalty of online grocery shoppers is affected by another factor or group of factors, which can be explained by the uniqueness and difference of online groceries from other online products. Also, Mortimer et al. (2016) confirm that the experience of online grocery shopping is different from other forms of online shopping. This can be caused by a tendency to repeat purchases in online grocery shopping, which is more frequent than other online shopping (Opreana, 2013). Previous research on store loyalty has mostly focused on factors such as in-store experience and social embeddedness (Yoon \& Park, 2018), satisfaction, value for money (Grosso et al., 2018) image, and innovation (Moliner-Velázquez et al., 2019). There is a lot of loyaltyoriented research for offline customers or online customers, but this research is oriented on differences between both groups. The researchers suggest that brand loyalty differs in online and offline purchasing contexts (Saini \& Lynch, 2016; Danaher et al., 2003). It was found that the relationship between customer and brand (i.e. customer loyalty) is stronger in the online than offline context (Shankar, 2003; Hult et al., 2018). Based on the literature review oriented on online and offline grocery shoppers, the following hypotheses were formulated:

Hypothesis 3: Customers purchasing groceries online perceive new technologies in grocery retail more positively than in-store grocery shoppers do. 
Hypothesis 4: In the case of traditional retailers entering the online market, customers purchasing groceries online are more loyal to their online retailer than customers purchasing groceries offline.

\section{Methodology}

The research is oriented on the perception of loyalty and new technologies used in grocery retailing from the generations' perspective and shopping environment used. The Baby Boomers, Generation X, and Generation Y were selected as the current largest customer base of retailing organizations. The first step in the research was to conduct data cleaning and provide a preliminary data analysis. This process is described in the following section together with detailed sample characteristics (see Table 1).

Subsequently, it was tested whether the Baby Boomers, Generation X and Generation $Y$ (as a segmentation criterion) were significant and suitable for further testing. After confirming the applicability of this criterion, a test of the independence of selected respondents' responses was performed using Pearson's chi-quadrate test (see subchapter 2.2.). Frequency analysis was then used for a more detailed examination of the observed dependencies between the variables. This procedure was also applied to data segmentation by online and offline customer group criterions.

\subsection{Research sample and data analysis}

The data for this study were collected through IPSOS online respondent panel. All completed questionnaires amounted to 1,050 respondents. Their answers have a nominal character. Data analysis did not find any missing values or consistency problem. This paper examines grocery customers on two levels. The first level represents the whole research sample as grocery customers overall (not depending on buying channel - H1). The second level divides grocery customers into two groups: online grocery shoppers and in-store grocery shoppers $(\mathrm{H} 2 ; \mathrm{H} 3 ; \mathrm{H} 4)$. The following table presents a detailed view of the sample characteristic of the selected groups. 
Table 1 | Sample characteristics for online and offline purchaser groups

\begin{tabular}{|l|c|c|c|c|c|c|}
\hline \multirow{2}{*}{ Demographic features } & \multicolumn{2}{|c|}{$\begin{array}{c}\text { Online grocery } \\
\text { shoppers } \\
(\mathbf{N = 2 8 8}\end{array}$} & $\begin{array}{c}\text { In-store grocery } \\
\text { shoppers } \\
(\mathbf{N = 7 6 2})\end{array}$ & \multicolumn{2}{c|}{$\begin{array}{c}\text { All groups } \\
\text { (N=1050) }\end{array}$} \\
\cline { 2 - 7 } & Count & Percent & Count & Percent & Count & Percent \\
\hline Gender & & & & & & \\
\hline Female & 144 & 50.0 & 356 & 46.7 & 500 & 47.6 \\
\hline Male & 144 & 50.0 & 406 & 53.3 & 550 & 52.3 \\
\hline Generation & & & & & & \\
\hline Baby Boomers & 69 & 24.0 & 234 & 30.7 & 303 & 28.8 \\
\hline Generation X & 95 & 33.0 & 227 & 29.8 & 322 & 30.6 \\
\hline Generation Y & 124 & 43.1 & 301 & 39.5 & 425 & 40.4 \\
\hline Education & & & & & & \\
\hline Basic & 88 & 30.6 & 266 & 34.9 & 354 & 33.7 \\
\hline Secondary without A-level & 26 & 9.0 & 68 & 8.9 & 94 & 8.9 \\
\hline Secondary with A-level & 120 & 41.7 & 303 & 39.8 & 423 & 40.2 \\
\hline Tertiary & 54 & 18.8 & 125 & 16.4 & 179 & 17.0 \\
\hline Distribution by city size & & & & & & \\
\hline Up to 1,000 inhabitants & 48 & 16.7 & 119 & 15.6 & 167 & 15.9 \\
\hline $1,001-5,000$ inhabitants & 59 & 20.5 & 163 & 21.4 & 222 & 21.1 \\
\hline $5,001-20,000$ inhabitants & 35 & 12.2 & 142 & 18.6 & 177 & 16.8 \\
\hline $20,001-100,000$ inhabitants & 52 & 18.1 & 170 & 22.3 & 222 & 21.1 \\
\hline More than 100,001 inhabitants & 94 & 32.6 & 168 & 22.0 & 262 & 24.9 \\
\hline
\end{tabular}

Source: author

\subsection{Statistical methods}

In his discussion of the chi-square test, Sharpe (2015) summarized this method as the most popular of non-parametric or distribution-free tests and the default choice when analysing categorical data. He stated that chi-square tests will never be considered sexy even though they remain important and useful methods for applied researchers seeking to evaluate categorical data. Due to the nature of the data obtained, Pearson's chi-square was used for testing. Comparing cells was used as an approach to investigate chi-square tests results. This approach evaluates whether specific cells differ from each other (Sharpe, 2015). The chi-square test for larger contingency tables than $2 \times 2$ can be used if a maximum of $20 \%$ of the expected frequencies are less than 5 and none are less than 1 (Field, 2013). 


\section{Results}

In this section, the results of statistical analyses performed in IBM SPSS Statistics are presented. The results are structured into three parts focused on verifying hypotheses based on the literature review.

\subsection{The perception of new technologies in grocery retail from the point of view of generations}

The first step in the analysis of the perception of new technologies from the point of view of individual generations was the implementation of the goodness of fit test (Chi-square test with one sample). It was found from this test that the selected nominal variable (generation) was representative of specified population distribution. The statistical significance was less than 0.05 , therefore the null hypothesis was rejected (sig. $=0.000<0.05=\mathrm{H} 1$ is not rejected). The Chi-square was 24.623 and no cells had expected frequencies less than 5 . The minimum expected cell frequency was not less than one. Thus, affiliation to a particular generation had an impact (i.e. is statistically significant) on the questionnaire.

Since the statistical test showed that belonging to a particular generation may have an impact on respondent's answers, the second step was to carry out a Chi-square test to determine whether customer generation related to the perception of technologies. Table 2 provides a summary of Chi-square tests results. All tests met assumptions by Field (2013) because no cells had expected frequencies less than 5 and the minimum expected cell frequency was not less than one. The results indicated that only the association between smart shopping carts and customer generation is not statistically significant, $X 2(2)=0.78, p=0.677$. For all other variables examined, the null hypothesis that our variables are independent of the entire population was rejected. Based on the testing, it can be assumed that belonging to a particular generation is related to the perception of Scan\&Go (sig. $=0.023<0.05=>\mathrm{H} 0$ is rejected), self-service cash registers (sig. $=0.000<0.05 \Rightarrow \mathrm{HO}$ is rejected), and customerization support technologies (sig. $=0.000<0.05=>\mathrm{H} 0$ is rejected). The contingency coefficient was negligible in the case of Scan\&Go. The rest of the technologies had a weak contingency coefficient.

Table 2 | Relations between the perception of technologies and customers' generation perspective

\begin{tabular}{|l|c|c|c|c|}
\hline Technologies & $\begin{array}{c}\text { Chi-square } \\
\text { value }\end{array}$ & df & $\begin{array}{c}\text { Contingency } \\
\text { Coefficient }\end{array}$ & Sig. \\
\hline Scan\&Go & 7.52 & 2 & 0.084 & $(0.023)^{\star}$ \\
\hline Self-service cash registers & 21.50 & 2 & 0.142 & $(0.000)^{\star *}$ \\
\hline $\begin{array}{l}\text { Customerization support } \\
\text { technologies }\end{array}$ & 17.82 & 2 & 0.129 & $(0.000)^{\star *}$ \\
\hline Smart shopping carts & 0.78 & 2 & - & $(0.677)$ \\
\hline
\end{tabular}

${ }^{* *} p<0.01,{ }^{*} p<0.05$

Source: author

The more detailed analysis, shown in Table 3, presents the count and percentage of respondents who positively perceive individual technologies and their use in grocery retail. The gap between generations in the perception of smart shopping carts is almost none, as 
confirmed by the chi-square test. Nevertheless, it can be said that Generation X perceived this technology, as well as Scan\&Go technology, in the most positive way. The other two technologies, self-service cash registers and customerization support technologies, were perceived in the most positive light by Generation Y. Nearly $67 \%$ of respondents of this generation would like to use these technologies in retail. Generation $X$ tended to favour selfservice cash registers above all other technologies and $61 \%$ of them would like to use it in retail. For the Baby Boomers, smart shopping carts technology were the most well-received amongst all other technologies.

Table 3 Perception of technologies in retailing by customers' generation perspective

\begin{tabular}{|l|r|r|r|r|r|r|}
\hline \multirow{2}{*}{ Technologies } & \multicolumn{2}{|c|}{ Generation Y } & \multicolumn{2}{c|}{ Generation X } & \multicolumn{2}{c|}{ Baby Boomers } \\
\cline { 2 - 7 } & Count & Percent & \multicolumn{1}{c|}{ Count } & Percent & Count & Percent \\
\hline Scan\&Go & 223 & 52.47 & 184 & 57.14 & 140 & 46.20 \\
\hline self-service cash registers & 284 & 66.82 & 197 & 61.18 & 151 & 49.83 \\
\hline $\begin{array}{l}\text { customerization support } \\
\text { technologies }\end{array}$ & 284 & 66.82 & 183 & 56.83 & 157 & 51.82 \\
\hline smart shopping carts & 246 & 57.88 & 196 & 60.87 & 176 & 58.09 \\
\hline Mean of percentages & & 61.00 & & 59.01 & & 51.49 \\
\hline
\end{tabular}

Source: author

It is necessary to generalize the results of the analysis to confirm or reject hypothesis 1 . Through reference to the decreasing mean of the percentage of respondents who perceive the technology positively (part of Table 3), hypothesis 1 can be confirmed. Therefore, the positive perception of new technologies in grocery retail does diminish with the growing age range of generations of customers purchasing groceries. The previous results confirmed the first hypothesis, but there is a question of consistency when the factor of online grocery shopping acceptance is included. In order to evaluate the second hypothesis, it is necessary to use the results of relations between the perception of technologies and customers' generation and relations between the perception of technologies and technology acceptance of online grocery shopping in a table (see Table 5). Therefore, the following table includes also the results of the previous table but with a different perspective on the research problem. 
Table 4 | Perception of technologies in retailing from the perspective of generations of offline customers and online customers

\begin{tabular}{|c|c|c|c|c|c|c|c|}
\hline \multirow{2}{*}{\multicolumn{2}{|c|}{ Technologies }} & \multicolumn{2}{|c|}{ Generation $Y$} & \multicolumn{2}{|c|}{ Generation X } & \multicolumn{2}{|c|}{ Baby Boomers } \\
\hline & & Count & Percent & Count & Percent & Count & Percent \\
\hline \multicolumn{2}{|l|}{ Scan\&Go } & 78 & 62.90 & 63 & 66.32 & 37 & 53.62 \\
\hline \multicolumn{2}{|c|}{ self-service cash registers } & 94 & 75.81 & 70 & 73.68 & 42 & 60.87 \\
\hline \multicolumn{2}{|c|}{$\begin{array}{l}\text { customerization support } \\
\text { technologies }\end{array}$} & 99 & 79.84 & 71 & 74.74 & 39 & 56.52 \\
\hline \multicolumn{2}{|c|}{ smart shopping carts } & 94 & 75.81 & 77 & 81.05 & 50 & 72.46 \\
\hline \multirow{2}{*}{$\begin{array}{l}\text { Mean of } \\
\text { percentages }\end{array}$} & Offline & \multicolumn{2}{|c|}{$61.00^{*}$} & \multicolumn{2}{|c|}{$59.01^{*}$} & \multicolumn{2}{|c|}{$51.49^{*}$} \\
\hline & Online & \multicolumn{2}{|c|}{73.59} & \multicolumn{2}{|c|}{73.95} & \multicolumn{2}{|c|}{60.87} \\
\hline
\end{tabular}

* The results of offline customers taken from Table 3

Source: author

The results prove that the previous acceptance of technologies enabling online grocery shopping has a positive impact on the perception of technologies in retailing overall. By comparing the averages of positive perception of technology in retailing from the perspectives of offline and online customers, the results suggest more positive responses in the case of online customers, independent of the age group. The mean percentages increase was highest in the case of Generation X (this difference is nearly 15\%) while a significant increase was also found in Generation $Y$ where nearly $13 \%$ of respondents perceived new technologies in retailing as positive. It was also found that in the case of Baby Boomers acceptance of online grocery shopping has a positive impact on their perception of new technologies in retailing because the difference between the groups examined is nearly $10 \%$. Thus, Baby Boomers can see new technologies in retailing more positively if they have already bought groceries online. These results confirmed the assumption that acceptance of online grocery shopping diminishes the negative perception of new technologies in grocery retail, particularly when considered in terms of the growing age range of generations of customers purchasing groceries.

\subsection{The impact of online grocery shopping acceptance on the perception of new technologies in grocery retail}

The goodness of fit test provided found that the selected nominal variable (online/only offline grocery shopper) is representative of specified population distribution. The statistical significance was less than 0.05 , therefore the null hypothesis was rejected. The Chi-square was 214.68 and no cells had expected frequencies less than 5 . The minimum expected cell frequency was not less than one. Thus, technology acceptance of online grocery shopping (OGS) is statistically significant in the questionnaire. After the goodness of fit, the chi-square test was used to determine whether customer acceptance of OGS related to the perception of technologies (see Table 5). There were no cells with expected frequencies less than 5 and the minimum expected cell frequency was not less than one. Furthermore, the contingency coefficient tests showed a weak dependence of variables. 
Table 5 | Relations between the perception of technologies and technology acceptance of OGS

\begin{tabular}{|l|c|c|c|c|}
\hline Technologies & $\begin{array}{c}\text { Chi-square } \\
\text { value }\end{array}$ & df & $\begin{array}{c}\text { Contingency } \\
\text { Coefficient }\end{array}$ & Sig. \\
\hline Scan\&Go & 14.99 & 1 & 0.119 & $(0.000)^{\star *}$ \\
\hline Self-service cash registers & 21.29 & 1 & 0.141 & $(0.000)^{\star *}$ \\
\hline $\begin{array}{l}\text { Customerization support } \\
\text { technologies }\end{array}$ & 28.42 & 1 & 0.162 & $(0.000)^{\star *}$ \\
\hline Smart shopping carts & 52.39 & 1 & 0.218 & $(0.000)^{\star *}$ \\
\hline
\end{tabular}

${ }^{* *} p<0.01$

Source: author

The chi-square test confirmed that the acceptance of online grocery shopping affects the perception of new technologies in retail. It was, however, necessary to analyse individual numbers (percentages) of respondents for a more detailed understanding of this impact. These respondents were divided into two groups, those who purchase grocery online as well as those who only purchase grocery offline.

The "online grocery shoppers" group had a more positive perception of technologies tested than "in-store grocery shoppers" group (see Table 6). The difference was also present in the case of the most positively perceived technology in each group where almost $78 \%$ of online grocery shoppers perceived smart shopping carts as the most favoured option, while almost $56 \%$ of respondents from the second group perceived self-service cash registers in the best light.

Table 6 | Perception of technologies by customers group

\begin{tabular}{|l|c|c|c|c|c|}
\hline \multirow{2}{*}{ Technologies } & \multicolumn{2}{|c|}{$\begin{array}{c}\text { Online grocery } \\
\text { shoppers } \\
\text { (N= 288) }\end{array}$} & \multicolumn{2}{c|}{$\begin{array}{c}\text { In-store grocery } \\
\text { shoppers } \\
\text { (N = 762) }\end{array}$} & $\begin{array}{c}\text { Difference } \\
\text { between } \\
\text { groups }\end{array}$ \\
\cline { 2 - 6 } & Count & Percent & Count & Percent & Percent \\
\hline Scan\&Go & 178 & 61.81 & 369 & 48.43 & 13.38 \\
\hline $\begin{array}{l}\text { Self-service cash } \\
\text { registers }\end{array}$ & 206 & 71.53 & 426 & 55.91 & 15.62 \\
\hline $\begin{array}{l}\text { Customerization } \\
\text { support technologies }\end{array}$ & 209 & 72.57 & 415 & 54.46 & 18.11 \\
\hline Smart shopping carts & 221 & 76.74 & 397 & 52.10 & 24.64 \\
\hline
\end{tabular}

Source: author

It is clear from Table 6 that the "online grocery shoppers" group perceives new technologies in grocery retail, on average, $18 \%$ more positively than the "in-store grocery shoppers" group. Based on this finding, it can be stated that hypothesis 3 is confirmed. The customers purchasing groceries online perceive new technologies in grocery retail more positively than in-store grocery shoppers do. 


\subsection{The impact of online grocery shopping acceptance on customer loyalty in the case of traditional grocery retailers' entry into the online marketplace}

The final relationship considered was the loyalty of online grocery shoppers and in-store grocery shoppers in the case of the entrance of traditional grocery retailers to the online marketplace. Kaufland, Lidl and Globus were selected for this research. Theses grocery retailers currently do not offer online grocery shopping and they belong to the largest grocery retailers in the Czech Republic. These retail chains were chosen because they are the only large retail chains (with the exception of Tesco which has already introduced online grocery shopping on this market) to think that they will start offering groceries online in the Czech Republic. More detailed information focused on retail sales, the number of stores, experience with online sales, and plans for online grocery sales of these retailers in the Czech Republic are summarized in the following table.

Table 7 | Characteristics of retail chains surveyed (data and information corresponding only to the Czech Republic)

\begin{tabular}{|l|c|c|c|c|}
\hline $\begin{array}{l}\text { Grocery } \\
\text { retailer }\end{array}$ & $\begin{array}{c}\text { Retail } \\
\text { sales (in } \\
\text { billions of } \\
\text { CZK) }\end{array}$ & $\begin{array}{c}\text { Number of } \\
\text { own stores } \\
\text { (October } \\
\text { 2018) }\end{array}$ & $\begin{array}{c}\text { Provisional } \\
\text { experience with } \\
\text { online sales }\end{array}$ & $\begin{array}{c}\text { Plan to start offering grocery } \\
\text { online in the Czech Republic }\end{array}$ \\
\hline Kaufland & 56.84 & 131 & Not yet & $\begin{array}{c}\text { Yes, they are considering an } \\
\text { investment (but they have a } \\
\text { negative experience with selling } \\
\text { groceries online in Berlin) }\end{array}$ \\
\hline Lidl & 43.75 & 238 & $\begin{array}{c}\text { Only non-food } \\
\text { products }\end{array}$ & $\begin{array}{c}\text { Yes (it offers online grocery } \\
\text { shopping in 11 countries outside } \\
\text { the Czech Republic) }\end{array}$ \\
\hline Globus & 22.84 & 15 & $\begin{array}{c}\text { Butcher } \\
\text { products only }\end{array}$ & $\begin{array}{c}\text { Yes (so far they are testing online } \\
\text { grocery selling in retail in Zličín - } \\
\text { Prague) }\end{array}$ \\
\hline
\end{tabular}

Source: own illustration based on secondary data of official retailers' websites

Based on the chi-square independence test results, it can be reported that an association between online grocery shopping acceptance and choosing a Kaufland, Lidl or Globus was observed (for all variables is a sig. $=0.000<0.05=>\mathrm{H} 0$ is rejected). The results of chi-square independence test are presented in Table 8.

Table 8 | Relations between the entrance of traditional grocery retailers and grocery shoppers' groups

\begin{tabular}{|l|c|c|c|c|}
\hline Grocery retailers & Chi-square value & df & $\begin{array}{c}\text { Contingency } \\
\text { Coefficient }\end{array}$ & Sig. \\
\hline Kaufland & 59.03 & 1 & 0.231 & $(0.000)^{* *}$ \\
\hline Lidl & 25.13 & 1 & 0.153 & $(0.000)^{* *}$ \\
\hline Globus & 56.14 & 1 & 0.225 & $(0.000)^{* *}$ \\
\hline
\end{tabular}

${ }^{* *} p<0.01$

Source: author

The factor of loyalty was measured by the percentage of respondents who would start shopping with traditional grocery retailers if they entered the online market (i.e. switching frequency) (Martos-Partal \& González-Benizo, 2013). Figure 1 shows that in this case, online 
grocery shoppers changed merchants more than in-store grocery shoppers. Both groups would most likely start purchasing at Lidl, followed by Globus and then Kaufland. There are almost no differences between grocery retailer selections in the case of the online grocery shopper group. The situation is different in the second group tested. The difference between the selection of Lidl and the remaining two retailers is an average of 15 percent.

Figure 1 | The loyalty of customer groups when traditional grocery retailers enter the online market

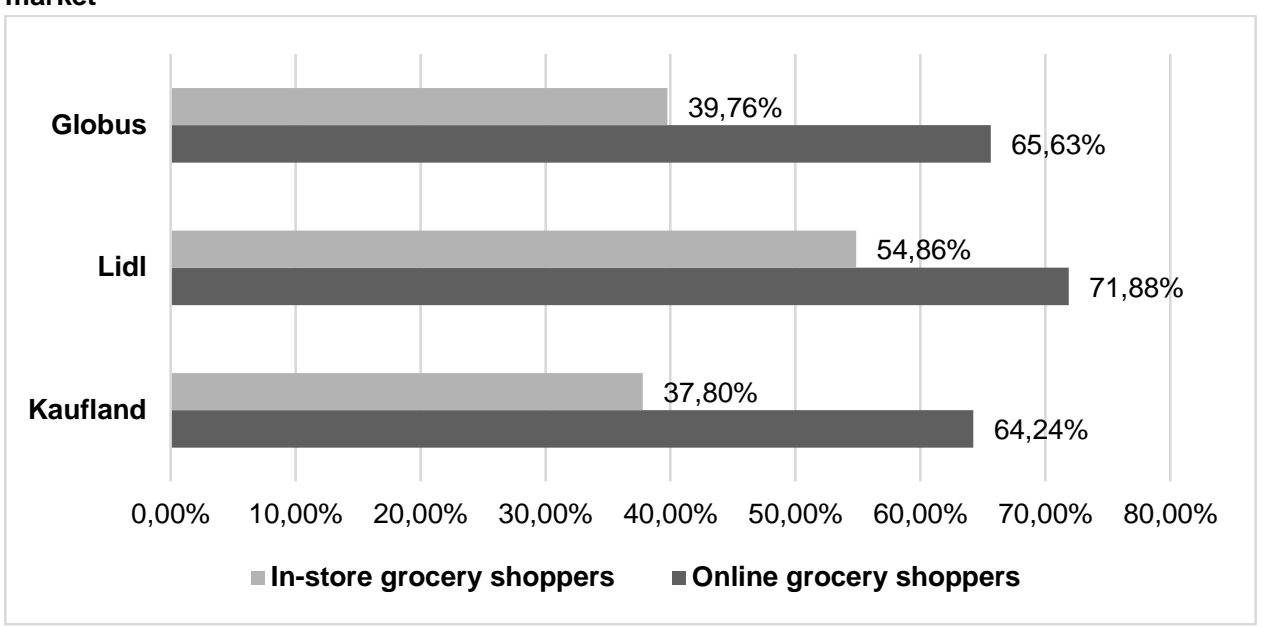

Source: author

On average, $67 \%$ of online grocery shoppers would choose one of the traditional grocery retailers if they started selling groceries online, while only $44 \%$ of in-store grocery shoppers would change their retailer. Based on this finding, Hypothesis 4 is rejected. It can be said, therefore, that customers purchasing groceries online are not more loyal to their online retailer than customers purchasing groceries offline in the case of traditional retailers entering the online market.

\section{Discussion}

The aim of this paper was to explore whether online grocery shopping acceptance affects the perception of new technologies and loyalty in grocery retailing. It was found that online grocery shopping acceptance can be stated as one of the assumptions of the positive perception of other technologies in retailing. In addition, a relationship between online grocery shopping and customers' loyalty was found. The results of the analysis show a very positive perception of new technologies in grocery retail by customers, but also the potential of an online form for traditional offline grocery retailers.

The first part of the research has shown how Generations $X$ and $Y$ and Baby Boomers perceive technologies that can be used in grocery retail. Generation $Y$ perceives new technologies in grocery retailing the most positive. On average, a total of $61 \%$ of them would use new technologies in grocery retailing if available. However, there is almost no difference between Generation $Y$ and $X$ because only $2 \%$ fewer customers belonging to Generation $X$ would use new technologies in grocery retailing if available. Baby Boomers perceived new 
technologies in retail less positive than previous generations but $51 \%$ of customers in this group would still use these technologies if grocery retailers offered them. The results indicate great interest in using new technologies in all generations examined. These conclusions are consistent with those of other researchers who found that different generations adapt to new technologies in varied ways (Slootweg \& Rowson, 2018; Fox, 2014). Further investigation revealed that the previous acceptance of technologies enabling online grocery shopping has a positive impact on the perception of technologies in retailing. All generations examined see new technologies in retailing more positively if they have already accepted online grocery shopping.

In the second part of the research, it was confirmed that the technology acceptance of online grocery shopping affects the perception of new technologies in the retail sector overall. It has been found that online grocery shoppers perceive new technologies in grocery retail more positively than in-store grocery shoppers, which was also suggested by Maat and Konings (2018). Online grocery shoppers favour smart shopping carts most, which may indicate the need to know the value of the purchase during the shopping process and time-saving; two factors present in the web environment as well. In contrast, in-store grocery shoppers perceive self-service cash registers in the most favourable light. This technology has already been in use by some retailers on the Czech market for some time, which may indicate conservative technology choices and slower acceptance of new technologies of in-store grocery shoppers.

The research results suggested that loyalty is also different for online grocery shoppers than for in-store grocery shoppers as Saini and Lynch (2016) or Danaher et al. (2003) claimed. While $67 \%$ of online grocery shoppers would choose one of the traditional grocery retailers if they would begin offering products online, only $44 \%$ of in-store grocery shoppers would do so. While other researchers have found that the relationship between customer and brand (i.e. customers' loyalty) is stronger in the online context than offline (Shankar, 2003; Hult et al., 2018), this has not been confirmed in our research. This is probably due to a situation where traditional grocery retailers are still waiting to enter the online market, which is confirmed by the fact that $67 \%$ of online customers would change their retailer if traditional retailers would begin to offer online grocery shopping.

\section{Conclusions}

Despite the fact that the differences between Generations $X$ and $Y$ and Baby Boomers have been identified and confirmed in the perception of new technologies in grocery shopping, these differences are in the range of ten percent. This paper has a scientific contribution to the theory of generations, as it has been found that the difference between these generations is very slight (i.e. negligible or weak contingency coefficient). In addition, the results confirm that accepting online grocery shopping changed the perception of new technologies, which increased in all categories of generations in a positive way (12 percent on average). This paper brings a new perspective on customers' generations when using new technologies in retailing in the idea that it affects every generation in the same direction. The results confirmed that the accepting of technology in retail by customers is an important assumption for the positive perception of other technologies. In this way, managers should take steps to increase the acceptance of technologies in stores, which will not only facilitate purchases by 
customers but also the business processes in the store through reduced labour costs and increased efficiency of in-store workers.

Loyalty results revealed two particular insights. The first is that most online customers are in fact not loyal to their online grocery retailer and, if possible, will change it. Secondly, almost half of in-store customers would start purchasing groceries online if Lidl, Globus, or Kaufland were to offer online grocery shopping. This situation demonstrates great potential for traditional grocery retailers to begin offering groceries online. This research has managerial implications for retailers who can use research results to increase their competitiveness. This is due to the fact that the implementation of new technologies examined can help to garner the attention of potential customers in both offline and online environments, in addition to saving on labour costs while increasing customer satisfaction.

The limits of this study are based on the type of primary data itself. These data are of nominal character only and therefore only chi-square testing can be used. The limit of this type of independent test is the possibility to test only two variables at one time. This does not make it possible to compare more variables with each other. The next problem may be with the format of answers in the questionnaire, which did not allow scaling, thereby eliminating the potential for respondents to include nuances between the real perceptions of the questions.

Research has confirmed that the perception of new technologies and their acceptance is related to the affiliation to a certain generation and its acceptance of online grocery shopping. Since the differences between Generations $X$ and $Y$ and Baby Boomers was only in the range of ten percent, it would be appropriate to carry out continuous research and to see if these differences are even more modest. The second factor suggests either that customers purchasing groceries online are more open to new technologies in grocery retail, or that prior acceptance of technology in grocery retail may affect the acceptance of other technologies in this field. Of course, both options may be valid at the same time, indicating the possibility of further research as well.

\section{Acknowledgement}

This research was financially supported by the Student grant competition project SGS/7/2017: "Acceptance of technology from the perspective of marketing tools."

\section{References}

Anderson, J. L., Jolly, L. D., \& Fairhurst, A. E. (2007). Customer relationship management in retailing: A content analysis of retail trade journals. Journal of Retailing and Consumer Services, 14(6), 394399, https://doi.org/10.1016/j.jretconser.2007.02.009.

Azhar, K. A., \& Bashir, D. M. A. (2018). Understanding e-Loyalty in Online Grocery Shopping. International Journal of Applied Business and International Management, 3(2), 37-56, https://doi.org/10.32535/ijabim.v3i2.158.

Bauerova, R. (2018). Evaluation of Online Grocery Shopping Based on the Hype Curve Concept. In T. Kliestik (Ed.), Proceedings of 18th International Scientific Conference on Globalization and its socio-economic consequences (pp. 1959-1966). Slovakia, Rajecke Teplice: University of Zilina. 
Bauerova, R., \& Klepek, M. (2018). The Digitalization of a Grocery Shopping from a Generation Perspective. In L. Cabyova, R. Rybansky, \& Z. Bezakova (Eds.), Marketing Identity: Digital Mirrors, Pt I (pp. 243-255). Trnava: Univ Ss Cyril \& Methodius Trnava-Ucm Trnava.

Chen, J. V., Yen, D. C, Pornpriphet, S., \& Widjaja, A. E. (2015). E-commerce web site loyalty: A cross cultural comparison. Information Systems Frontiers, 17(6), 1283-1299, https://doi.org/10.1007/s10796-014-9499-0.

Danaher, P. J., Wilson, I. S. \& Davis, R. A. (2003). A Comparison of Online and Offline Consumer Brand Loyalty. Marketing Science, 22(4), 461-476, https://doi.org/10.1287/mksc.22.4.461.24907.

Dolnicar, S., Grün, B., \& Leisch, F. (2018). Market Segmentation Analysis: Understanding It, Doing It, and Making It Useful. New York: Springer Berlin Heidelberg.

Esch, P., Arli, D., Gheshlaghi, M. H., Andonopoulos, V., von der Heidt, T., \& Northey, G. (2019). Anthropomorphism and augmented reality in the retail environment. Journal of Retailing and Consumer Services, 49, 35-42. https://doi.org/10.1016/j.jretconser.2019.03.002

Field, A. (2013). Discovering Statistics Using IBM SPSS Statistics. London: Sage Publications Ltd.

Flanc, J. B. (2014). Valuation of Internet Start-ups: An Applied Research on How Venture Capitalists value Internet Start-ups. Hamburg: Anchor Academic Publishing.

Fleisher, C. S., \& Bensoussan, B. E. (2015). Business and Competitive Analysis: Effective Application of New and Classic Methods. New Jersey: FT Press.

Gandhi, A, Magar, C., \& Roberts, R. (2013). How technology can drive the next wave of mass customization. McKinsey Quarterly, 32.

Grewal, D., Roggeveen, A. L., \& Nordfält, J. (2017). The Future of Retailing. Journal of Retailing, 93(1), 1-6, https://doi.org/10.1016/j.jretai.2016.12.008.

Grosso, M., Castaldo, S., \& Grewal, A. (2018). How store attributes impact shoppers' loyalty in emerging countries: An investigation in the Indian retail sector. Journal of Retailing and Consumer Services, 40, 117-124, https://doi.org/10.1016/j.jretconser.2017.08.024.

Harris, P., Riley, F. D., Riley, D., \& Hand, C. (2017). Online and store patronage: a typology of grocery shoppers. International Journal of Retail \& Distribution Management, 45(4), 419-445. https://doi.org/10.1108/IJRDM-06-2016-0103

Hernández, B., Jiménez, J., \& José Martín, M. (2011). Age, gender and income: do they really moderate online shopping behaviour? Online Information Review, 35(1), 113-133, https://doi.org/10.1108/14684521111113614.

Hole, D., Zhong, L., \& Schwartz, J. (2012). Talking About Whose Generation? Why Western generational models can't account for a global workforce. Birmingham: Deloitte Development LLC. (5).

Huang, T. L. (2019). Psychological mechanisms of brand love and information technology identity in virtual retail environments. Journal of Retailing and Consumer Services, 47, 251-264. https://doi.org/10.1016/j.jretconser.2018.11.016

Hult, G. T. M., Sharma, P. N., Morgeson, F. V., \& Zhang, Y. (2019). Antecedents and Consequences of Customer Satisfaction: Do They Differ Across Online and Offline Purchases? Journal of Retailing, 95(1), 10-23, https://doi.org/10.1016/j.jretai.2018.10.003.

Inc, E. M., \& Linsenmann, C. (2015). Start Your Own Retail Business and More: Brick-and-Mortar StoresOnline-Mail Order-Kiosks. Irvine: Entrepreneur Press. 
Inman, J. J., \& Nikolova, H. (2017). Shopper-Facing Retail Technology: A Retailer Adoption Decision Framework Incorporating Shopper Attitudes and Privacy Concerns. Journal of Retailing, 93(1), 7-28, https://doi.org/10.1016/j.jretai.2016.12.006.

Ittersum, K., Wansink, B., Pennings, J. M. E., \& Sheehan, D. (2013). Smart Shopping Carts: How RealTime Feedback Influences Spending. Journal of Marketing, 77(6), 21-36, https://doi.org/10.1509/jm.12.0060.

Izogo, E. E., \& Jayawardhena, C. (2018). Online shopping experience in an emerging e-retailing market. Journal of Research in Interactive Marketing, 12(2), 193-214. https://doi.org/10.1108/JRIM-022017-0015

Jocevski, M., Arvidsson, N., Miragliotta, G., Ghezzi, A., \& Mangiaracina, R. (2019). Transitions towards omni-channel retailing strategies: a business model perspective. International Journal of Retail \& Distribution Management, 47(2), 78-93. https://doi.org/10.1108/IJRDM-08-2018-0176

Kim, E., Libaque-Saenz, C. F., \& Park, M. C. (2019). Understanding shopping routes of offline purchasers: selection of search-channels (online vs. offline) and search-platforms (mobile vs. PC) based on product types. Service Business, 13(2), 305-338. https://doi.org/10.1007/s11628018-0384-7

Maat, K. \& Konings, R. (2018). Accessibility or Innovation? Store Shopping Trips versus Online Shopping. Transportation Research Record, 2672(50), 1-10, https://doi.org/10.1509/jm.12.0060.

Martos-Partal, M., \& González-Benito, Ó. (2013). Studying motivations of store-loyal buyers across alternative measures of behavioural loyalty. European Management Journal, 31(4), 348-358, https://doi.org/10.1016/j.emj.2013.01.010.

Moliner-Velázquez, B., Fuentes-Blasco, M., Servera-Francés, D., \& Gil-Saura, I. (2019). From retail innovation and image to loyalty: moderating effects of product type. Service Business, 13(1), 199-224, https://doi.org/10.1007/s11628-018-0378-5.

Mortimer, G. S., \& Weeks, C. S. (2011). Grocery product pricing and Australian supermarket consumers: gender differences in perceived importance levels. The International Review of Retail, Distribution and Consumer Research, 21(4), 361-373, https://doi.org/10.1080/09593969.2011.596553.

Munson, J., Tiropanis, T., \& Lowe, M. (2017). Online Grocery Shopping: Identifying Change in Consumption Practices. In I. Kompatsiaris, J. Cave, A. Satsiou, G. Carle, A. Passani, E. Kontopoulos (Eds.), Internet Science (pp. 192-211). Cham: Springer International Publishing.

Opreana, A. (2013). Examining Online Shopping Services in Relation to Experience and Frequency of Using Internet Retailing. Expert Journal of Marketing, 1(1), 17-27.

Pantano, E., \& Priporas, C. V. (2016). The effect of mobile retailing on consumers' purchasing experiences: A dynamic perspective. Computers in Human Behavior, 61, 548-555, https://doi.org/10.1016/j.chb.2016.03.071.

Pantano, E., \& Vannucci, V. (2019). Who is innovating? An exploratory research of digital technologies diffusion in retail industry. Journal of Retailing and Consumer Services, 49, 297-304. https://doi.org/10.1016/j.jretconser.2019.01.019

Pantano, E., Priporas, C. V., Sorace, S., \& lazzolino, G. (2017). Does innovation-orientation lead to retail industry growth? Empirical evidence from patent analysis. Journal of Retailing and Consumer Services, 34, 88-94, https://doi.org/10.1016/j.jretconser.2016.10.001.

Rogers, M. (2005). Customer Strategy: Observations from the Trenches. Journal of Marketing, 69(4), 262-263, https://doi.org/10.1509/jmkg.2005.69.4.262. 
Saini, Y. K., \& Lynch, J. G. (2016). The effects of the online and offline purchase environment on consumer choice of familiar and unfamiliar brands. International Journal of Research in Marketing, 33(3), 702-705, https://doi.org/10.1016/j.jiresmar.2016.02.003.

Shankar, V., Smith, A. K., \& Rangaswamy, A. (2003). Customer satisfaction and loyalty in online and offline environments. International Journal of Research in Marketing, 20(2), 153-175, https://doi.org/10.1016/S0167-8116(03)00016-8.

Sharpe, D. E. (2015). Your Chi-Square Test Is Statistically Significant: Now What? Practical Assessment, Research \& Evaluation, 20(8), 1-10.

Slootweg, E., \& Rowson, B. (2018). My generation: A review of marketing strategies on different age groups. Research in Hospitality Management, 8(2), 85-92-92, https://doi.org/10.1080/22243534.2018.1553369.

Violante, M. G., Vezzetti, E., \& Piazzolla, P. (2019). How to design a virtual reality experience that impacts the consumer engagement: the case of the virtual supermarket. International Journal on Interactive Design and Manufacturing (IJIDeM), 13(1), 243-262. https://doi.org/10.1007/s12008018-00528-5

Wiley S. (2019, April) Understanding Today's Workforce: Generational Differences and the Technologies They Use. Retrieved April 15, 2019, from https://www.firmofthefuture.com/content/understanding-todays-workforce-generationaldifferences-and-the-technologies-they-use/.

Wind, J., \& Rangaswamy, A. (2001). Customerization: The next revolution in mass customization. Journal of Interactive Marketing, 15(1), 13-32, https://doi.org/10.1002/15206653(200124)15:1<13::AID-DIR1001>3.0.CO;2-\#.

Yoon, S., \& Park, J. E. (2018). Tests of in-store experience and socially embedded measures as predictors of retail store loyalty. Journal of Retailing and Consumer Services, 45, 111-119, https://doi.org/10.1016/j.jretconser.2018.08.010.

The research paper has been reviewed. | Received: July 8, 2019; Revised: August 9, 2019; Accepted: August 11, 2019; Prepublished online: September 23, 2019; Published: October 1, 2019 